(2) Open Access Full Text Article

REVIEW

\title{
Microwave ablation: state-of-the-art review
}

\author{
José Irving Hernández \\ Mario Francisco Jesús \\ Cepeda \\ Francisco Valdés \\ Geshel David Guerrero \\ Instituto Tecnológico de la Laguna, \\ Torreón, Mexico
}

This article was published in the following Dove Press journal:

OncoTargets and Therapy

6 July 2015

Number of times this article has been viewed

\begin{abstract}
This paper reviews state-of-the-art microwave ablation (MWA) of tumors. MWA is a novel method for treating inoperable tumors, ie, tumors that cannot be treated surgically. However, patients generally choose removal of the tumor by conventional techniques. A literature review of MWA for breast, liver, lung, and kidney tumors is reported here, with tabulation of our findings according to the type of technique used, with a detailed description of the time, type of microwave generator used, and number of patients treated with MWA. In some cases, the subjects were not human patients, but pig or bovine liver specimens. MWA is a technique that has proved to be promising and likely to be used increasingly in the ablation of cancerous tumors. However, MWA needs to be used more widely to establish itself as a common tool in the treatment of inoperable tumors.
\end{abstract}

Keywords: tumor, ablation, microwave, review

\section{Introduction}

A tumor is a swelling of a part of the body, generally without inflammation, caused by an abnormal growth of tissue, whether benign or malignant. ${ }^{1}$ Tumors can be cancerous (malignant) or non-cancerous (benign), and occur when cells multiply excessively in the body. Normally, the division and growth of cells occurs in a controlled manner. New cells are created all the time to replace old ones or to perform new functions. Cells that are damaged or are no longer needed die off and are replaced with fresh cells. If the balance of division and cell death is altered, a tumor may appear. ${ }^{2}$

According to 2012 World Health Organization statistics, the most frequent types of cancer worldwide (ranked according to number of deaths globally) are of the lung, prostate, colon, rectum, stomach, and liver (in men), and breast, colon, rectum, lung, cervix, and stomach (in women). There are several methods available to treat cancerous tumors, the most common being surgery, radiotherapy, and systemic chemotherapy. ${ }^{3}$ With early detection of tumors, it is possible to use a minimally invasive new technique that works by increasing the temperature inside the tumor hyperthermia, while avoiding damage to healthy adjacent tissue. ${ }^{4}$

\section{Tumor ablation}

Placement of a needle or catheter directly into a tumor and the use of heat, cold, or a chemical to destroy it is known as ablation. It is used most frequently to stop the spread of cancer to the bones or liver, although it can also be used in other organs. Ablation is usually employed when only a limited number of tumors are causing problems.

A common type of ablation, ie, radiofrequency ablation, uses a needle that carries an electric current. The end of the needle is placed into the tumor. Ultrasound or computed tomography can be used to ensure that the needle is correctly positioned. An electrical
Correspondence: José Irving Hernández Blvd Revolución esq Cuauhtémoc, Col Centro, Torreón, Coahuila de Zaragoza, CP 27000, Mexico

Tel +5287 I705 I3।3

Email joseirving@itlalaguna.edu.mx 
Table I Ablation of pig and bovine liver and lung tumors

\begin{tabular}{|c|c|c|c|c|}
\hline Microwave generator & Antenna & Time & Patients/tumors & Comments \\
\hline $\begin{array}{l}2,450 \mathrm{MHz}^{-} \\
70-100 \mathrm{~W}^{5}\end{array}$ & $\begin{array}{l}\text { Microsulis Americas } \\
\text { Inc, Waltham, } \\
\text { MA, USA, } 5.7 \mathrm{~mm} \\
\text { diameter }\end{array}$ & 4 minutes & Pig liver & $\begin{array}{l}\text { Good in liver tissue. The ablation } \\
\text { diameters were } 3-6.45 \mathrm{~cm} \text {. }\end{array}$ \\
\hline $\begin{array}{l}915 \mathrm{MHz}^{-1} \\
50-80 \mathrm{~W}^{6}\end{array}$ & $\begin{array}{l}1.9 \mathrm{~mm} \text { diameter } \\
\text { antenna }\end{array}$ & 10 minutes & Bovine liver & $\begin{array}{l}\text { Two antennas were used to achieve } \\
\text { a larger and more spherical zone } \\
\text { of ablation and coagulation. More } \\
\text { desirable coagulation geometry could } \\
\text { be obtained by simultaneous application } \\
\text { of double antennae at } 70 \mathrm{~W} \text {. }\end{array}$ \\
\hline $\begin{array}{l}2,450 \mathrm{MHz} \\
60 \text { or } 80 \mathrm{~W}^{7}\end{array}$ & I4 gauge antenna & 10 minutes & 8 pig livers & $\begin{array}{l}\text { Effective control of the ablation zone } \\
\text { was achieved. }\end{array}$ \\
\hline $\begin{array}{l}2,450 \mathrm{MHz} \\
60 \mathrm{~W}^{8}\end{array}$ & I4 gauge antenna & 10 minutes & $\begin{array}{l}\text { I5 pigs with } 56 \\
\text { tumors }\end{array}$ & $\begin{array}{l}\text { Three different antenna arrays were } \\
\text { compared. The three-antenna array was } \\
\text { connected to the death of two pigs. }\end{array}$ \\
\hline
\end{tabular}

current is then passed through the needle, heating the tumor and destroying it. In general, radiofrequency ablation is done while the patient is under general anesthesia. ${ }^{9}$ Another type of ablation, known as cryoablation, uses a probe placed inside the tumor to freeze it, which destroys cancer cells. ${ }^{10}$ Other methods use heat (laser-induced interstitial thermotherapy) or alcohol to destroy cells. ${ }^{11}$

\section{Microwave tumor ablation}

Microwaves are being used increasingly in medicine for ablation of tumors, causing them to be burned and destroyed. Several prototype antennae have been used to perform microwave ablation (MWA). These antennae are designed to be as small as possible and with increasingly precise targeting power to prevent damage to healthy tissue.

Table 2 Ablation of liver tumors in patients

\begin{tabular}{|c|c|c|c|c|}
\hline Microwave generator & Antenna & Time & Patients/tumors & Comments \\
\hline $915 \mathrm{MHz}$ & $3.7 \mathrm{~cm}$ of effective & 10 minutes & 6 patients with 16 liver & They require improvements before \\
\hline $40 W^{12}$ & radiation & & metastases & MWA can be used on a routine basis. \\
\hline $\begin{array}{l}2,450 \mathrm{MHz}^{2} \\
20-80 \mathrm{~W}^{13}\end{array}$ & $\begin{array}{l}\text { I4 gauge, Amica-Gen, } \\
\text { HS Hospital Service }\end{array}$ & $8-10$ minutes & 6 patients & $\begin{array}{l}5 \text { patients showed disease-free } \\
\text { survival. }\end{array}$ \\
\hline $20-80 W^{13}$ & SpA, Aprilia, Italy & & & \\
\hline \multirow[t]{3}{*}{$915 \mathrm{MHz}, 2,450 \mathrm{MHz}^{14}$} & $1-3$ & 9.7 minutes with & 48 patients with 124 & Both systems manage ablation of liver \\
\hline & I3 gauge antennae & $915 \mathrm{MHz}, 6.6$ minutes & tumors, 72 with 915 & tumors but the $2,450 \mathrm{MHz}$ system \\
\hline & & with $2,450 \mathrm{MHz}$ & $\mathrm{MHz}, 52$ with 2,450 MHz & $\begin{array}{l}\text { achieves more rapid and predictable } \\
\text { ablations. }\end{array}$ \\
\hline $2,450 \mathrm{MHz}$ & $5 \mathrm{~mm}$ antenna & 4 minutes & 140 patients in 18 & Morbidity was $8.3 \%$ and in-hospital \\
\hline $100 W^{15}$ & & & $\begin{array}{l}\text { hospitals with } 299 \\
\text { tumors }\end{array}$ & mortality was $1.9 \%$ \\
\hline $902-928 \mathrm{MHz}$ & I4 gauge antenna & 10 minutes & 10 tumors in 10 patients & 6 of $<3 \mathrm{~cm}$ tumors showed \\
\hline $10-32 W^{16}$ & & & (5 male, 5 female) & $\begin{array}{l}\text { complete necrosis and the rest had } \\
50 \% \text { partial necrosis. }\end{array}$ \\
\hline $2,450 \mathrm{MHz}$ & 14 or 16 gauge & $5-15$ minutes & 736 patients with 1,037 & 22 major complications and 54 minor \\
\hline $60-100 W^{17}$ & antenna & & tumors in 14 hospitals & $\begin{array}{l}\text { complications were observed, with } \\
\text { no mortality. }\end{array}$ \\
\hline $915 \mathrm{MHz}$ & Not specified & 10 minutes & 87 patients with 224 & The mortality rate was $2.3 \%$, local \\
\hline $45 W^{18}$ & & & tumors & $\begin{array}{l}\text { recurrence occurred in } 6 \text { tumors and } \\
\text { regional recurrence occurred in } 37 \\
\text { tumors. }\end{array}$ \\
\hline $915 \mathrm{MHz}$ and & I4.5 gauge antenna & 10 minutes & 15 patients with 19 & $100 \%$ success, with only 2 cases of \\
\hline \multirow[t]{4}{*}{$2,450 \mathrm{MHz}^{19}$} & for the $915 \mathrm{MHz}$ & & inoperable tumors & complications at 8 months of follow- \\
\hline & generator and I4 & & & up. A $915 \mathrm{MHz}$ generator was used \\
\hline & gauge antenna for the & & & in II patients and $2,450 \mathrm{MHz}$ in the \\
\hline & $2,450 \mathrm{MHz}$ generator & & & remaining 4. \\
\hline
\end{tabular}

Abbreviation: MVA, microwave ablation. 
Table 3 Ablation of lung tumors in patients

\begin{tabular}{|c|c|c|c|c|}
\hline Microwave generator & Antenna & Time & Patients/tumors & Comments \\
\hline $\begin{array}{l}915 \mathrm{MHz} \\
45 \mathrm{~W}^{20}\end{array}$ & $\begin{array}{l}\text { I } 4.5 \text { gauge } \\
\text { antenna }\end{array}$ & 10 minutes & $\begin{array}{l}24 \text { patients with } 26 \\
\text { inoperable tumors }\end{array}$ & $\begin{array}{l}\text { Technical success in } 100 \%, \\
\text { without major complications. I, } 3 \text {, } \\
\text { and } 6 \text { months and annually follow, } \\
\text { was observed complete necrosis } \\
\text { in } 61.6 \% \text { of lesions. Partial } \\
\text { necrosis in } 30.8 \% \text { and progression } \\
\text { of disease in only one case. }\end{array}$ \\
\hline $\begin{array}{l}2,450 \mathrm{MHz} \\
120 \mathrm{~W} \text { or } 180 \mathrm{~W}^{21}\end{array}$ & $\begin{array}{l}\mathrm{I} .8 \mathrm{~mm} \\
\text { diameter } \\
\text { antenna }\end{array}$ & $\begin{array}{l}180 \mathrm{~W} \text { : } \\
2 \text { minutes in }<2 \mathrm{~cm} \\
\text { tumors, } 3.5 \text { minutes in } \\
2-3 \mathrm{~cm} \text { tumors, } 4-6 \\
\text { minutes in } 3-5 \mathrm{~cm} \text { tumors } \\
120 \mathrm{~W} \text { : } \\
\text { I minute for } 1 \mathrm{~cm} \text { tumors, } \\
8 \text { minutes for } 2.4 \mathrm{~cm} \\
\text { tumors }\end{array}$ & $\begin{array}{l}23 \text { patients with } 29 \\
\text { tumors }\end{array}$ & $\begin{array}{l}\text { Recurrence was assessed at I, } \\
3 \text {, and } 6 \text { months after ablation. } \\
\text { In } 93 \% \text { of patients ablation was } \\
\text { successful, } 6 \text { months of local } \\
\text { recurrence was identified in } 3 \text { of } \\
26 \text { lesions, giving a local control } \\
\text { rate of } 88 \% \text {. }\end{array}$ \\
\hline $\begin{array}{l}902-928 \mathrm{MHz} \\
10-32 \mathrm{~W}^{22}\end{array}$ & $\begin{array}{l}\text { I4 gauge } \\
\text { antenna }\end{array}$ & 10 minutes & 10 patients & $\begin{array}{l}5 \text { of } 10 \text { specimens were clearly } \\
\text { measurable with a maximum } \\
\text { diameter of ablation of } 4.8 \mathrm{~cm} \\
\text { and volume of zone of ablation } \\
\text { was on average } 15.1 \mathrm{~cm} \text {. }\end{array}$ \\
\hline $\begin{array}{l}915 \mathrm{MHz} \\
45 \mathrm{~W}^{23}\end{array}$ & $\begin{array}{l}\text { I4.5 } \\
\text { gauge } \\
\text { antenna }\end{array}$ & 10 minutes & $\begin{array}{l}9 \text { patients with } 10 \\
\text { tumors }\end{array}$ & $\begin{array}{l}\text { Patients were followed up at I, } \\
3 \text {, and } 6 \text { months, concluding that } \\
\text { MWA is a valid alternative to } \\
\text { other techniques of ablation. }\end{array}$ \\
\hline
\end{tabular}

Abbreviation: MVA, microwave ablation.

The expectations generated by MWA have also sparked other investigations. ${ }^{24-27}$ Researchers are developing such antennae to generate heat via microwaves, as show in figure 1, and more patents are being granted for different antenna designs. The development of new software tools and other advances have led to the appearance of new methods for application of microwaves to ablate tumors. ${ }^{28-32}$ The figure 2 show the simulation of Microwave applicator inserted in breast tissue. Many research groups are investigating the effectiveness of MWA in the treatment of cancer. As they progress, there are more studies published on the evaluation, the comparison to other techniques and the application of ablation using microwaves. ${ }^{33-46}$ The tables included in this paper show the main features of some of the studies published in recent years.
Table 1 shows that MWA offers a good ablation zone of approximately $3-4 \mathrm{~cm}$ (in one experiment, the ablation zone was $6.45 \mathrm{~cm}$ ). In the last study mentioned in this table, the applicator was an array of three antennae, and the paper concludes that a single antenna can ablate tumors less than $4 \mathrm{~cm}$ in length and avoid damage to the lung.

The tables that follow show the results using different applicators to treat tumors in human patients. Many researchers have used the liver to test MWA because it is an organ that is difficult to operate on, and therefore alternative treatments, such as MWA, are appealing. Table 2 shows that MWA is an effective alternative treatment, with outcomes similar to those of surgery. The difference between the test frequencies was the therapy time; a frequency of $2,450 \mathrm{MHz}$ allows more ablation than others. In further clinical trials conducted

Table 4 Ablation of kidney tumors in patients

\begin{tabular}{|c|c|c|c|c|}
\hline Microwave generator & Antenna & Time & Patients/tumors & Comments \\
\hline $\begin{array}{l}915 \mathrm{MHz} \\
45 \mathrm{~W}^{47}\end{array}$ & I4.5 gauge antenna & 10 minutes & 12 patients & $\begin{array}{l}\text { Patients had a 3-14-month follow-up to observe } \\
\text { the therapeutic effects and complications. There } \\
\text { were no serious complications or unexpected } \\
\text { side effects after ablation. }\end{array}$ \\
\hline $\begin{array}{l}2,450 \mathrm{MHz} \\
50 \mathrm{~W}^{48}\end{array}$ & $\begin{array}{l}\text { I } 5 \text { gauge antenna } \\
\text { coated with ethylene } \\
\text { polytetrafluoride }\end{array}$ & 8 minutes & $\begin{array}{l}48 \text { patients with MWA, } \\
54 \text { patients with partial } \\
\text { nephrectomy }\end{array}$ & $\begin{array}{l}\text { 3-year survival was } 91.3 \% \text { for MWA and } 96 \% \\
\text { for partial nephrectomy. }\end{array}$ \\
\hline
\end{tabular}

Abbreviation: MVA, microwave ablation. 


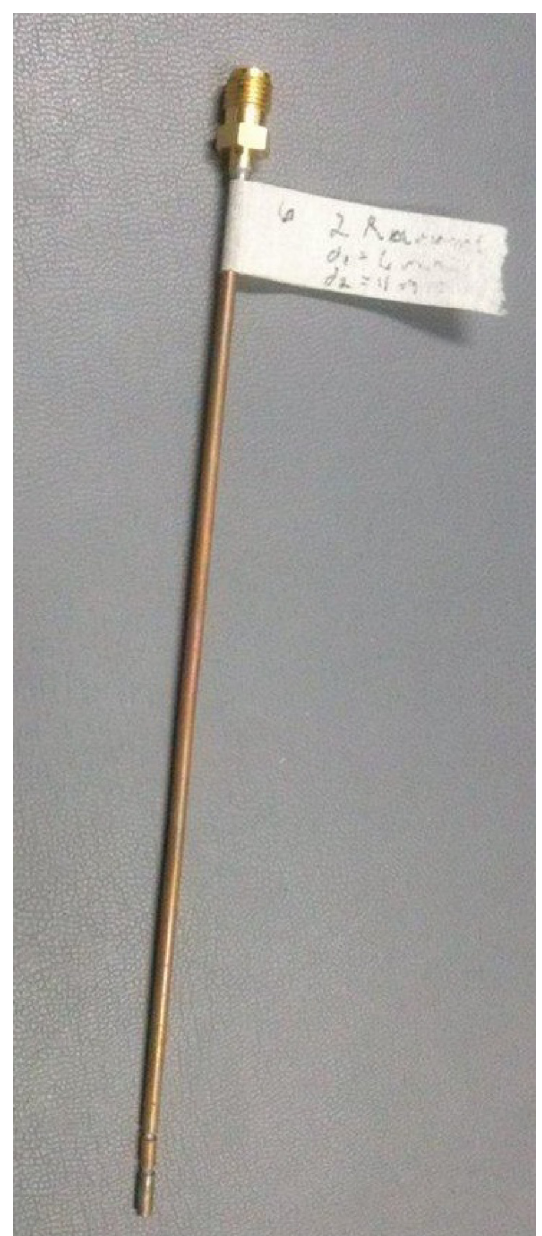

Figure I Applicator for microwave ablation.

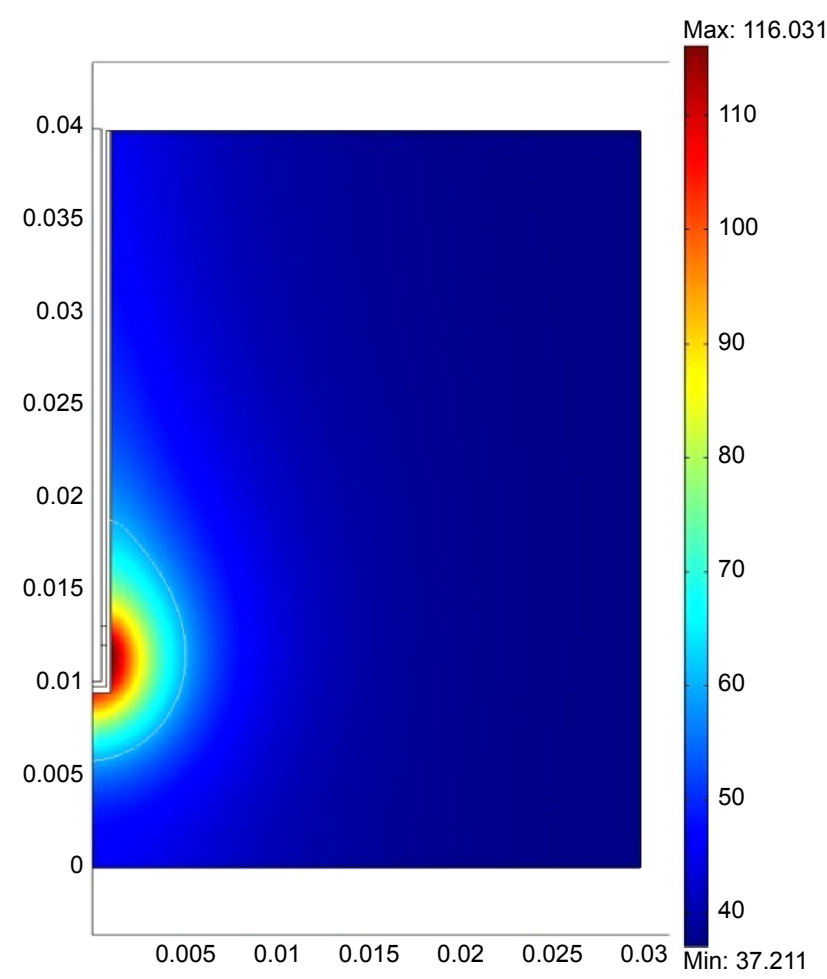

Figure 2 Simulation of microwave applicator inserted in breast tissue.

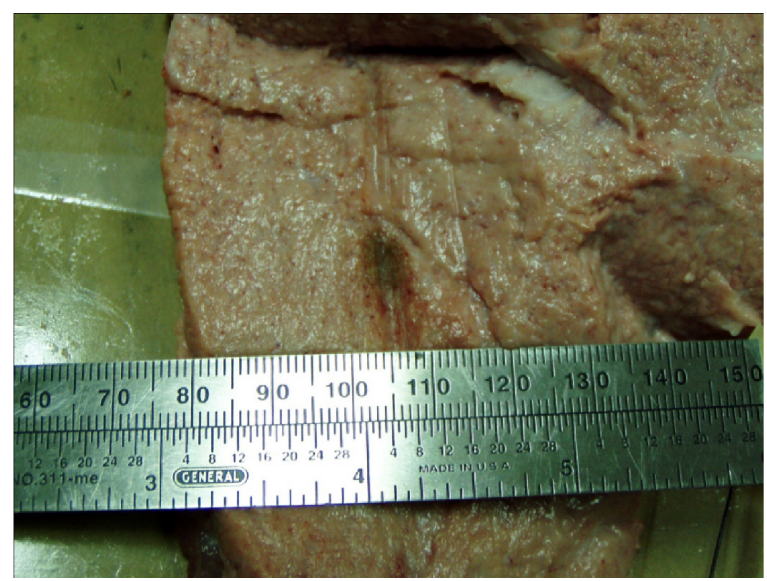

Figure 3 Ablation of breast tissue ex vivo at $2,450 \mathrm{MHz}$ and $10 \mathrm{~W}$.

in 60 patients with 96 tumors measuring $1-8 \mathrm{~cm}$, complete ablation was observed in 89 tumors. $^{7}$

The conclusion of Tables 3 and 4 is similar to that for liver tumors, ie, MWA is a viable treatment option for lung and kidney tumors, with results similar to those of surgery when patients are followed up at 1,3, and 6 months for lung and kidney tumors, and complete necrosis were seen in most patients.

There are presently no data available on the use of MWA in breast cancer. However, in 2011, Cepeda suggested using MWA for this type of cancer. Figure 3 shows the injury caused by the applicator, which was used in the ex vivo test. In his doctoral thesis, he elaborated the design of an applicator for minimally invasive MWA, performing a computational analysis by finite element modeling, and then validated the model with experiments on phantoms and ex vivo porcine tissue breast. ${ }^{49}$

\section{Conclusion}

MWA has proven to be a successful therapeutic tool in the treatment of cancer. Its use is expected to increase in frequency for ablation of tumors. Although many successful tests have been done, MWA has not progressed to widespread use in dedicated cancer treatment centers, in particular for inoperable tumors (even though most of the clinical studies have been done in people who could not be treated by surgery). The advantages of MWA need to be recognized more widely, given that it has been proven to be effective. Hospitals should consider acquiring the expertise and infrastructure needed to establish MWA for the treatment of cancers, and thus offer patients an alternative treatment option.

\section{Disclosure}

The authors report no conflicts of interest in this work. 


\section{References}

1. The Oxford English Dictionary. Oxford, UK: Oxford University Press; 2010.

2. National Service of Medicine of the United States. Available from: www.nlm.nih.gov. Accessed January, 2014.

3. World Health Organization. GLOBOCAN 2012: estimated cancer incidence, mortality and prevalence worldwide in 2012. Available from: http://www.who.int/cancer/en/. Accessed May 6, 2015.

4. Storm FK. Hyperthermia. Paper presented at the Microwave Symposium Digest, IEEE MTT-S International, June 15-19, 1981, Los Angeles, CA, USA.

5. Garrean S, Hering J, Saied A, et al. Ultrasound monitoring of a novel microwave ablation (MWA) device in porcine liver: lessons learned and phenomena observed on ablative effects near major intrahepatic vessels. J Gastrointest Surg. 2009;13(2):334-340.

6. Shi W, Liang P, Zhu Q, et al. Microwave ablation: results with double $915 \mathrm{MHz}$ antennae in ex vivo bovine livers. Eur J Radiol. 2011;79(2): 214-217.

7. Jiao D, Qian L, Zhang Y, et al. Microwave ablation treatment of liver cancer with 2,450-MHz cooled-shaft antenna: an experimental and clinical study. J Cancer Res Clin Oncol. 2010;136(10):1507-1516.

8. Planché $\mathrm{O}$, Teriitehau $\mathrm{C}$, Boudabous $\mathrm{S}$, et al. In vivo evaluation of lung microwave ablation in a porcine tumor mimic model. Cardiovasc Interv Radiol. 2013;36(1):221-228.

9. Tomas V, Jan V. Ablation applicator for destructive hyperthermia treatment. J Phys Conf Ser. 2011;329(1):012035.

10. Shinohara K. Cryotherapy. Int J Clin Oncol. 2007;12(6):416-426.

11. American Cancer Society. Available from: www.cancer.org. Accessed January 14, 2014.

12. Hompes R, Fieuws S, Aerts R, Thijs M, Penninckx F, Topal B. Results of single-probe microwave ablation of metastatic liver cancer. Eur J Surg Oncol. 2010;36(8):725-730.

13. Zanus G, Boetto R, Gringeri E, et al. Microwave thermal ablation for hepatocarcinoma: six liver transplantation cases. Transplant Proc. 2011;43(4):1091-1094.

14. Simo KA, Tsirline VB, Sindram D, et al. Microwave ablation using 915-MHz and 2.45-GHz systems: what are the differences? HPB (Oxford). 2013;15(12):991-996.

15. Lloyd DM, Lau KN, Welsh F, et al. International multicentre prospective study on microwave ablation of liver tumours: preliminary results. HPB (Oxford). 2011;13(8):579-585.

16. Ratanaprasatporn L, Charpentier KP, Resnick M, Lu S, Dupuy D. Intra-operative microwave ablation of liver malignancies with tumour permittivity feedback control: a prospective ablate and resect study. HPB (Oxford). 2013;15(12):997-1001.

17. Livraghi T, Meloni F, Solbiati L, Zanus G. Complications of microwave ablation for liver tumors: results of a multicenter study. Cardiovasc Interv Radiol. 2012;35(4):868-874.

18. Iannitti DA, Martin RCG, Simon CJ, et al. Hepatic tumor ablation with clustered microwave antennae: the US Phase II Trial. HPB (Oxford). 2007;9(2):120-124.

19. Veltri A, Gazzera C, Rotondella C, Camerano F, Busso M, Gandini G. Image-guided microwave ablation of hepatic tumours: preliminary experience. Radiol Med. 2012;117(3):378-392.

20. Carrafiello G, Mangini M, Fontana F, et al. Microwave ablation of lung tumours: single-centre preliminary experience. Radiol Med. 2014; 119(1):75-82.

21. Little M, Chung D, Boardman P, Gleeson F, Anderson E. Microwave ablation of pulmonary malignancies using a novel high-energy antenna system. Cardiovasc Interv Radiol. 2013;36(2):460-465.

22. Wolf FJ, Aswad B, Ng T, Dupuy DE. Intraoperative microwave ablation of pulmonary malignancies with tumor permittivity feedback control: ablation and resection study in 10 consecutive patients. Radiology. 2012; 262(1):353-360.

23. Carrafiello G, Mangini M, De Bernardi I, et al. Microwave ablation therapy for treating primary and secondary lung tumours: technical note. Radiol Med. 2010;115(6):962-974.
24. Cavagnaro M, Amabile C, Bernardi P, Pisa S, Tosoratti N. A minimally invasive antenna for microwave ablation therapies: design, performances, and experimental assessment. IEEE Trans Biomed Eng. 2011; 58(4):949-959.

25. Prakash P, Converse MC, Webster JG, Mahvi DM. An optimal sliding choke antenna for hepatic microwave ablation. IEEE Trans Biomed Eng. 2009;56(10):2470-2476.

26. Keangin P, Rattanadecho P, Wessapan T. An analysis of heat transfer in liver tissue during microwave ablation using single and double slot antenna. Int Comm Heat Mass Transfer. 2011;38(6):757-766.

27. He N, Wang W, Ji Z, Li C, Huang B. Microwave ablation: an experimental comparative study on internally cooled antenna versus noninternally cooled antenna in liver models. Acad Radiol. 2010;17(7): 894-899.

28. Phasukkit P, Sanpanich A, Tungjitkusolmun S, Hamamoto K. Effect of phase difference in multi-antenna microwave thermal ablation for breast cancer treatment. Conf Proc IEEE Eng Med Biol Soc. 2013;2013: 3718-3721.

29. Sindram D, Swan RZ, Lau KN, McKillop IH, Iannitti DA, Martinie JB. Real-time three-dimensional guided ultrasound targeting system for microwave ablation of liver tumours: a human pilot study. $H P B$ (Oxford). 2011;13(3):185-191.

30. Top CB, Gençer NG. Harmonic motion microwave Doppler imaging: a simulation study using a simple breast model. IEEE Trans Med Imaging. 2014;33(2):290-300.

31. Kurumi Y, Tani T, Naka S, et al. MR-guided microwave ablation for malignancies. Int J Clin Oncol. 2007;12(2):85-93.

32. Keangin P, Rattanadecho P. Analysis of heat transport on local thermal non-equilibrium in porous liver during microwave ablation. Int Comm Heat Mass Transfer. 2013;67:46-60.

33. Wu H, Exner AA, Krupka TM, Weinberg BD, Patel R, Haaga JR. Radiofrequency ablation: post-ablation assessment using CT perfusion with pharmacological modulation in a rat subcutaneous tumor model. Acad Radiol. 2009;16(3):321-331.

34. Denys A, Lachenal Y, Duran R, Chollet-Rivier M, Bize P. Use of highfrequency jet ventilation for percutaneous tumor ablation. Cardiovasc Intervent Radiol. 2014;37(1):140-146.

35. Swan R, Sindram D, Martinie J, Iannitti D. Operative microwave ablation for hepatocellular carcinoma: complications, recurrence, and long-term outcomes. J Gastrointest Surg. 2013;17(4):719-729.

36. Simo KA, Sereika SE, Newton KN, Gerber DA. Laparoscopicassisted microwave ablation for hepatocellular carcinoma: safety and efficacy in comparison with radiofrequency ablation. J Surg Oncol. 2011;104(7):822-829.

37. Skonieczki BD, Wells C, Wasser EJ, Dupuy DE. Radiofrequency and microwave tumor ablation in patients with implanted cardiac devices: is it safe? Eur J Radiol. 2010;79(3):343-346.

38. Brannan JD. Electromagnetic measurement and modeling techniques for microwave ablation probes. Conf Proc IEEE Eng Med Biol Soc. 2009;2009:3076-3078.

39. Martin RG, Scoggins C, McMasters K. Safety and efficacy of microwave ablation of hepatic tumors: a prospective review of a 5-year experience. Ann Surg Oncol. 2010;17(1):171-178.

40. Carrafiello G, Mangini M, Fontana F, et al. Complications of microwave and radiofrequency lung ablation: personal experience and review of the literature. Radiol Med. 2012;117(2):201-213.

41. Lubner MG, Brace CL, Hinshaw JL, Lee FT Jr. Microwave tumor ablation: mechanism of action, clinical results, and devices. J Vasc Interv Radiol. 2010;21(8):S192-S203.

42. Tanaka T, Westphal S, Isfort P, et al. Microwave ablation compared with radiofrequency ablation for breast tissue in an ex vivo bovine udder model. Cardiovasc Interv Radiol. 2012;35(4):914-920.

43. Zhu Y, Yang J. Microwave endometrial ablation for endometrial protection in women with breast cancer on adjuvant tamoxifen. $J$ Obstet Gynaecol Res. 2013;39(9):1411-1414.

44. Wolf FJ, Dupuy DE, Machan JT, Mayo-Smith WW. Adrenal neoplasms: effectiveness and safety of CT-guided ablation of 23 tumors in 22 patients. Eur J Radiol. 2012;81(8):1717-1723. 
45. Lehman D, Landman J. Cryoablation and radiofrequency for kidney tumor. Curr Urol Rep. 2008;9(2):128-134.

46. Siperstein A, Garland A, Engle K, et al. Local recurrence after laparoscopic radiofrequency thermal ablation of hepatic tumors. Ann Surg Oncol. 2000;7(2):106-113.

47. Carrafiello G, Mangini M, Fontana F, et al. Single-antenna microwave ablation under contrast-enhanced ultrasound guidance for treatment of small renal cell carcinoma: preliminary experience. Cardiovasc Interv Radiol. 2010;33(2):367-374.
48. Guan W, Bai J, Liu J, et al. Microwave ablation versus partial nephrectomy for small renal tumors: intermediate-term results. J Surg Oncol. 2012;106(3):316-321.

49. Cepeda MFJ. Estudio y Desarrollo de Aplicadores Coaxiales Tipo Slot de Ablación por Microondas para el Tratamiento Mínimamente Invasivo del Cáncer de Mama. México: Bioelectronica, Centro de Investigación y de Estudios Avanzados del Instituto Politécnico Nacional; 2011.

\section{Publish your work in this journal}

OncoTargets and Therapy is an international, peer-reviewed, open access journal focusing on the pathological basis of all cancers, potential targets for therapy and treatment protocols employed to improve the management of cancer patients. The journal also focuses on the impact of management programs and new therapeutic agents and protocols on

\section{Dovepress}

\footnotetext{
Submit your manuscript here: http://www.dovepress.com/oncotargets-and-therapy-journal
}

patient perspectives such as quality of life, adherence and satisfaction. The manuscript management system is completely online and includes a very quick and fair peer-review system, which is all easy to use. Visit http://www.dovepress.com/testimonials.php to read real quotes from published authors. 